Глєбова Є.Є.

\title{
Удосконалена модель організації медичної допомоги паціснтам з патологічними та віковими змінами шкіри
}

\author{
Національна медична академія післядипломної освіти імені П.Л. Шупика, м. Київ, Україна
}

doc.e.glebova@gmail.com

\author{
Глебова Е.Е. \\ Усовершенствованная модель организации \\ медицинской помощи пациентам \\ с патологическими и возрастными изменениями кожи \\ Национальная медицинская академия последипломного \\ образования имени П.Л. Шупика, г. Киев, Украина
}

\author{
Glebova E.E. \\ An improved model for organizing medical care \\ for patients with pathological \\ and age-related skin changes \\ Shupyk National Medical Academy \\ of Postgraduate Education, Kyiv, Ukraine
}

\section{Вступ}

Поступове, але неухильне зростання поширеності хвороб шкіри серед населення України, контингент хворих чисельністю більше 2-х млн осіб, зокрема, 3 хронічними дерматозами, псоріазом, новоутвореннями, інфекціями статевих органів, вимагають подальшого ефективного функціонування системи дерматовенерологічної допомоги з метою задоволення потреб населення у здоровій шкіри та їі придатках [6].

Поглиблюють проблеми шкіри чинники ризику іiі патологічних змін та передчасного старіння (нераціональне харчування, низька фізична активність населення, високий рівень споживання алкоголю, тютюнопаління, хронічні соматичні хвороби, патологія зубо-щелепного апарату, ортопедичні хвороби), широко розповсюджені серед української популяції $[3,7,10,11]$.

Дані твердження засновані на науково обгрунтованих фундаментальних знаннях про багатофункціональність шкіри як органу та іï тісний анатомо-фізіологічний зв'язок з нервовою, ендокринною, імунною, кістково-м“язовою системами, станом зубів [1].

Необхідність перегляду підходів до організації діяльності існуючої системи медичної допомоги пацієнтам 3 патологічними i віковими змінами шкіри значно посилюється активним розвитком ринку косметологічних послуг, потреби населення в яких постійно підвищуються внаслідок зростання значимості зовнішності як маркеру успішності та особистої культури людини, негативного впливу вікових змін шкіри на психоемоційний стан особи та якість життя $[2,4,5,8,9]$.

Доцільність удосконалення існуючої системи медичної допомоги пацієнтам з патологічними та віковими змінами шкіри обумовлюються й рекомендаціями експертів ВОО3 щодо переорієнтації надання медичних послуг від роздробленості до більшої інтеграції у рамках підходу, орієнтованого на людей, що є невідкладним у зв'язку з зростанням темпів хронічних захворювань та старіння населення Свропейського регіону [12].

Мета - розробити удосконалену модель організації медичної допомоги пацієнтам 3 патологічними та віковими змінами шкіри.

\section{Завдання, матеріали та методи дослідження}

Обгрунтувати удосконалену модель організації медичної допомоги пацієнтам 3 патологічними та віковими змінами шкіри, візуалізувати дану модель i визначити можливості її використання в практиці охорони здоров'я. Матеріалами слугували результати наукового дослідження автора, проведеного як фрагменту науководослідної роботи на тему «Обгрунтування моделей управління підсистемами охорони здоров'я та зміцнення здоров'я населення України відповідно до європейських стратегій» кафедри управління охороною здоров'я Національної медичної академії післядипломної освіти імені П.Л. Шупика (науковий керівник - академік НАМН України професор Ю.В. Вороненко; № держреєстрації 0120U101680; термін виконання 2015-2019 рр.). Методи дослідження: системного підходу, системного аналізу, синтезу, моделювання.

\section{Результати дослідження та їх обговорення}

Результати проведеного автором дослідження дозволили визначити ряд суттєвих обмежень для поступового розвитку існуючої системи надання медичної допомоги пацієнтам з патологічними та віковими змінами шкіри. Таким обмеженнями, на думку автора, слід вважати:

1) недосконалість вітчизняної нормативноправової бази з питань організації медичної допомоги, зокрема, спеціалізованої (у т. ч. дерматовенерологічної та iii складової - косметологічної) в частині забезпечення безперервного ланцюга медичних послуг, наступності 
різних видів і етапів медичної допомоги, оскільки в реальності залишається дієвою застаріла система направлень пацієнта до інших спеціалістів;

2) вузькоспеціалізований підхід до лікування хвороб шкіри та коригування вікових змін 3 боку провайдерів дерматологічних, зокрема, косметологічних, послуг, який полягає у застосуванні локальних втручань, підміні комплексного міждисциплінарного підходу до медичної допомоги призначенням комплексної терапії;

3) потребує удосконалення організація приватної медичної практики 3 надання дерматовенерологічних послуг, зокрема, косметологічної допомоги;

4) низький освітній рівень споживачів дерматологічних, зокрема, косметологічних, послуг 3 питань впливу та наслідків дії чинників ризику на загальний стан здоров'я, стан шкіри та зовнішній вигляд особи;

5) обмежене використання в дерматологічній, зокрема, косметологічній практиці, доказових технологій (міжнародних клінічних протоколів та систематичних оглядів);

6) обмежене використання наявних потужностей багатопрофільних закладів охорони здоров'я, де надається дерматологічна, зокрема, косметологічна допомога, в частині забезпечення пацієнт-орієнтованої комплексної медичної допомоги.

Виявлені недоліки спонукали автора до розробки удосконаленої міждисциплінарної моделі організації медичної допомоги пацієнтам 3 патологічними і віковими змінами шкіри (рис.)

Центральну роль в удосконаленій моделі відіграє пацієнт 3 патологічними i віковими змінами шкіри, оскільки основне призначення моделі - задовольнити потреби такого пацієнта в медичній допомозі. Крім пацієнта, зацікавленими сторонами в удосконаленій моделі $\epsilon$ держава, суспільство, органи місцевого самоврядування, заклади охорони здоров'я, медичні працівники, лікарські асоціації та інші інституції й особи.

Модель структурована за принципами системного підходу у класичний спосіб: 3 виокремленням суб'єкту управління, об'єкту управління, блоку наукової інформації.

В якості суб'єктів управління представлені МO3 України, керівники департаментів охорони здоров'я, закладів охорони здоров'я первинної, вторинної, третинної медичної допомоги усіх форм власності, закладів вищої медичної, у т. ч. післядипломної, освіти. Суб'єкти управління визначають політику функціонування галузі на відповідному рівні управління за напрямком «дерматовенерологічна допомога», яка спрямована на досягнення соціально значущої мети, а саме, покращення стану здоров'я населення України на основі комплексного підходу до надання медичної допомоги пацієнтам 3 патологічними і віковими змінами шкіри та пов'язаних 3 ними хронічними неінфекційними захворюваннями; профілактику передчасного старіння шкіри; покращення якості життя пацієнтів 3 патологічними та віковими змінами шкіри.
Цільовими завданнями для реалізації політики слід зазначити: організацію комплексної медичної допомоги пацієнтам з патологічними і віковими змінами шкіри та пов'язаних з ними неінфекційними захворюваннями (НI3); підвищити поінформованість населення 3 питань догляду за шкірою, профілактики шкірних хвороб та передчасного старіння; забезпечити безпеку і якість дерматологічної (зокрема, косметологічної) допомоги; підвищити рівень задоволеності медичною допомогою пацієнтів 3 патологічними та віковими змінами шкіри.

Стратегії реалізації завдань мають бути спрямовані на розвиток міждисциплінарних комунікацій і координацію діяльності: між фахівцями в межах закладу вторинної медичної допомоги; між фахівцями закладів первинної, вторинної, третинної, реабілітаційної медичної допомоги; удосконалення підходів до безперервного професійного розвитку (БПР) лікарів-дерматовенерологів, зокрема, 3 косметологічної допомоги; розширення спектру доказових технологій для надання медичної допомоги пацієнтам 3 патологічними і віковими змінами шкіри; використання безпечних косметологічних засобів і продуктів.

Управлінська діяльність суб'єктів управління спрямовується на об'єкти управління: заклади охорони здоров'я, лікарів-дерматовенерологів, лікарів інших спеціальностей, сестер медичних, у т. ч. 3 косметичних процедур; медичне обладнання; медичні технології, у т. ч. 3 надання косметологічної допомоги; інформаційні та комунікаційні технології; косметологічні засоби і продукти шляхом виконання класичних управлінських функцій: зі стратегічного та оперативно-тактичного планування, організації, комунікації, координації, мотивації персоналу, моніторингу, оцінки, аналізу результатів діяльності. Однак наповнення цих функцій має свої відмінності в удосконаленій моделі.

Так, функція стратегічного та оперативнотактичного планування полягає у:

1) розробці типових та, на їх основі, індивідуальних програм комплексної медичної допомоги пацієнтам 3 патологічними та віковими змінами шкіри, а також пов'язаними 3 ними хронічними неінфекційними захворюваннями: хворобами органів травлення, ендокринної, сечостатевої, нервової, кістково-м'язової системи, щелепно-лицевої ділянки та зубів;

2) організації розробки: нових клінічних протоколів (НКП) надання дерматологічної, у т. ч. косметологічної, допомоги, адаптованих до закладу охорони здоров'я; клінічних маршрутів пацієнта (КМП) з патологічними i віковими змінами шкіри та пов'язаними 3 ними хронічними неінфекційними захворюваннями в межах закладу вторинної медичної допомоги; «наскрізних клінічних маршрутів пацієнта (КМП)» для інших закладів охорони здоров'я - учасників виконання типових/ індивідуальних програм;

3) планування ресурсного забезпечення типових програм, зокрема, кадрового, для формування міждисциплінарних команд фахівців, та електронних засобів зв'язку; 


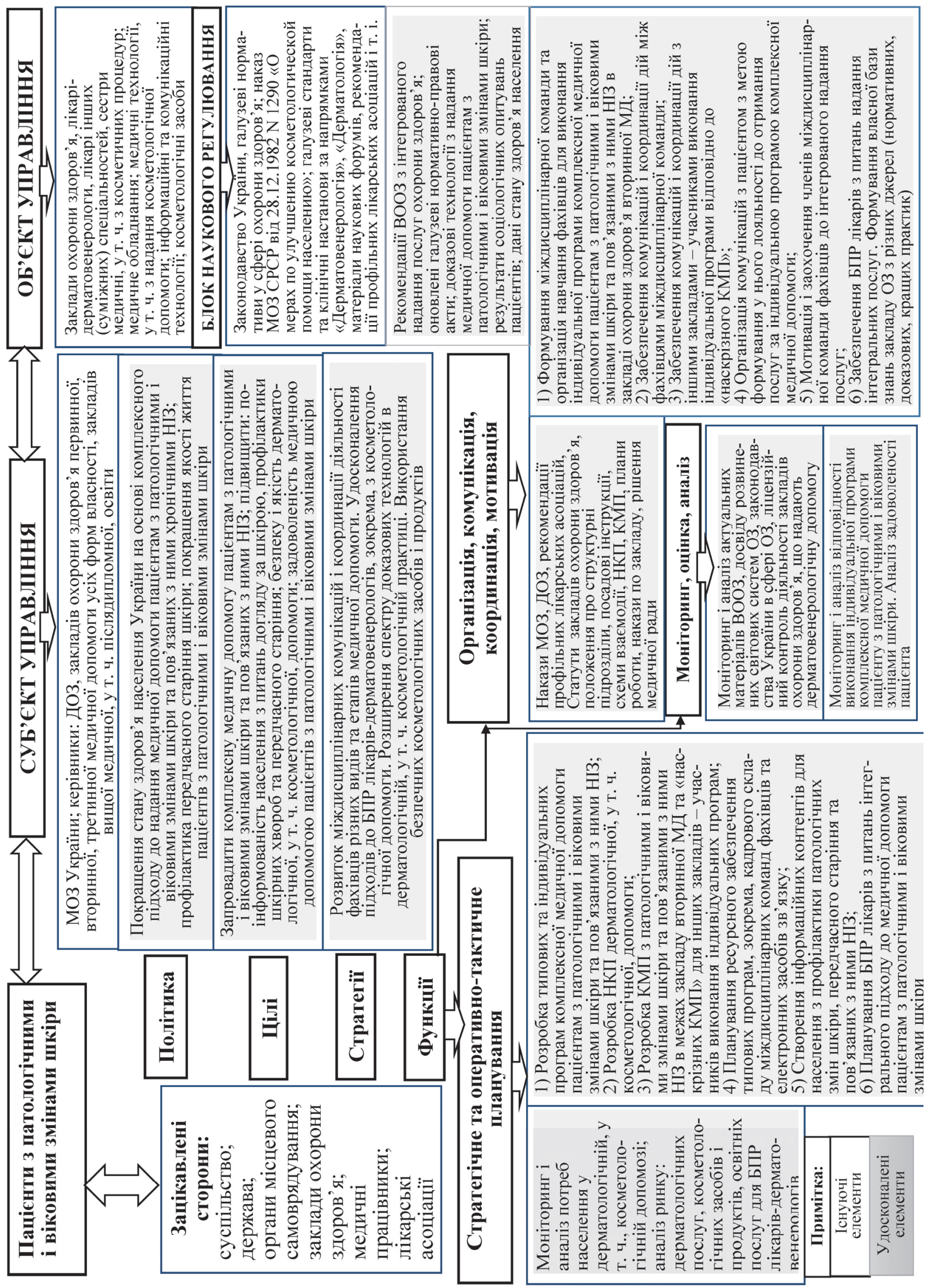

Рис. Удосконалена модель організації медичної допомоги пацієнтам з патологічними та віковими змінами шкіри 
4) створення інформаційних контентів 3 профілактики патологічних i вікових змін шкіри, передчасного старіння та пов'язаних 3 ними хронічних неінфекційних захворювань для населення; використання цифрових технологій 3 метою поширення освітньоінформаційних матеріалів;

5) планування безперервного професійного розвитку лікарів-дерматовенерологів та лікарів інших спеціальностей 3 питань інтегрального підходу до медичної допомоги пацієнтам 3 патологічними та віковими змінами шкіри.

В основу планування покладається аналіз стану здоров'я населення території обслуговування або визначеного за іншими критеріями контингенту, який користується послугами даного закладу охорони здоров'я; результати моніторингу 3 визначенням потреб у дерматологічній, у т. ч. косметологічній допомозі; аналіз ринку: дерматологічних послуг, косметологічних засобів i продуктів, освітніх послуг для забезпечення безперервного професійного розвитку лікарів.

Функція організації діяльності використовується при формуванні міждисциплінарної команди фахівців для виконання індивідуальної програми комплексної медичної допомоги пацієнту з патологічними і віковими змінами шкіри при зверненні пацієнта. Індивідуальна програма розробляється на основі типової програми з урахуванням загального стану здоров'я пацієнта. Як свідчать результати дослідження, патологічні та вікові зміни шкіри сполучаються в більшості випадків 3 патологією різних органів і систем, найчастіше, - ендокринної, сечостатевої, кістково-м'язової, шлунково-кишкового тракту, зубів, а також з психоемоційними порушеннями, які підтримують та/або поглиблюють патологічні та вікові зміни шкіри.

Формування міждисциплінарної команди здійснюється шляхом підбору спеціалістів в залежності від потреб пацієнта на основі попередньо узгодженого складу фахівців для типової програми з визначенням меж відповідальності кожного спеціаліста. Координатором команди призначається лікар-дерматовенеролог. Під час обстеження i лікування пацієнта може бути зміна координатора команди в залежності від проблеми здоров'я пацієнта, яка переважає. Проводиться оперативне навчання призначених членів команди з питань організації виконання індивідуальної програми комплексної медичної допомоги.

Під час роботи команди координатор в межах своїх повноважень забезпечує інформування членів команди про результати виконання програми на проміжних етапах та узгодження будь-яких питань, які можуть вплинути на результати медичної допомоги.

В разі, якщо в даному закладі охорони здоров'я відсутні спеціалісти необхідного профілю, керівник закладу забезпечує в оперативному режимі комунікації з іншими закладами охорони здоров'я на підставі попередніх угод 3 метою залучення їх фахівців до складу міждисциплінарної команди та координацію дій між членами команди відповідно до «наскрізного клінічного маршруту пацієнта» 3 використанням електронних засобів зв'язку та безпосереднього спілкування спеціалістів, за потреби.
Надання послуг за індивідуальною програмою комплексної медичної допомоги здійснюється за поінформованою згодою пацієнта. Мотивація пацієнта до отримання комплексних послуг може бути забезпечена шляхом освітньо-інформаційних заходів, коли пацієнту роз'яснюється доцільність і корисність міждисциплінарного підходу до лікування, комплексного оздоровлення організму, що вплине позитивно, зокрема, на стан шкіри та іï придатків. Використання матеріального компоненту мотивації, коли отримання послуг в комплексі має меншу вартість, ніж окремі види послуг в сумі, також сприяє прийняттю пацієнтом рішення на користь комплексної медичної допомоги.

Економічна складова мотивації використовується для заохочення членів міждисциплінарної команди, що відбувається в разі отримання позитивного кінцевого результату лікування пацієнта. Таким чином кожен член команди налаштовується на отримання позитивного результату за рахунок спільних зусиль та на власний професійний розвиток, без якого такий результат неможливий.

Класичні функції «зворотнього зв'язку» в удосконаленій моделі полягають у моніторингу і аналізі актуальних матеріалів ВОО3, досвіду розвинених світових систем охорони здоров'я, законодавства України в сфері охорони здоров'я 3 метою своєчасного внесення змін та подальшого розвитку удосконаленої системи відповідно до зовнішніх впливів. 3 боку МО3 України до таких функцій належить плановий ліцензійний контроль діяльності закладів охорони здоров'я, що надають дерматологічну допомогу.

В закладі охорони здоров'я здійснюється постійний моніторинг i аналіз відповідності виконання індивідуальної програми комплексної медичної допомоги пацієнту з патологічними і віковими змінами шкіри вимогам клінічних протоколів і клінічних маршрутів пацієнта координатором та членами міждисциплінарної команди. Кінцевий результат оцінюється пацієнтом як показник задоволеності та керівником закладу.

В існуючій системі надання медичної допомоги пацієнтам з патологічними і віковими змінами шкіри блок наукового регулювання містить законодавство України, галузеві нормативи в сфері охорони здоров'я в частині організації дерматовенерологічної допомоги. Зокрема, діючим залишається наказ МО3 СРСР від 28.12.1982 N 1290 «О мерах по улучшению косметологической помощи населению», який $\epsilon$ застарілим, російськомовним та невідповідним сучасному стану розвитку системи охорони здоров'я в Україні, зокрема, дерматовенерологічної допомоги. Доповнюють наукове регулювання галузеві стандарти та клінічні настанови за напрямками «Дерматовенерологія», «Дерматологія», яких обмаль, та матеріали наукових форумів. Доказові технології за напрямком «Косметологічна допомога» взагалі не використовуються, незважаючи на їх наявність у міжнародних джерелах.

В удосконаленій моделі системи пропонується до блоку наукового регулювання додати рекомендації 
експертів ВОО3 з інтегрованого надання послуг охорони здоров'я; оновлені галузеві нормативно-правові акти 3 організації дерматовенерологічної допомоги, відміна наказу МО3 СРСР від 28.12.1982 N 1290; нові клінічні протоколи 3 надання медичної допомоги пацієнтам 3 патологічними та віковими змінами шкіри; результати соціологічних опитувань паціснтів; дані стану здоров'я населення та аналіз демографічної ситуації.

Обгрунтована і розроблена удосконалена модель медичної допомоги пацієнтам 3 патологічними та віковими змінами шкіри може бути впроваджена в практичну діяльність багатопрофільних закладів охорони здоров'я будь-якої форми власності. В оцінці ефективності моделі за результатами впровадження полягають перспективи подальших досліджень.

\section{Висновки}

Таким чином, на основі авторського дослідження обгрунтовано і розроблено удосконалену модель медичної допомоги пацієнтам з патологічними та віковими змінами шкіри, ключовими інноваційними елементами якої слід вважати:
- комплексний підхід до надання медичної допомоги пацієнтам 3 патологією та віковими змінами шкіри;

- удосконалені технології освітньо-профілактичної роботи з населенням щодо обізнаності з питань чинників ризику патології шкіри та передчасного старіння;

- типові та, розроблені на їх основі, індивідуальні програми комплексної медичної допомоги пацієнту 3 патологічними та віковими змінами шкіри;

- міждисциплінарні команди фахівців різних спеціальностей, в залежності від стану здоров'я пацієнта, які виконуватимуть індивідуальні програми. Функції координатора програми покладаються на лікаря-спеціаліста в залежності від домінуючої проблеми у здоров 'ї пацієнта;

- безперервний професійний розвиток лікарівдерматовенерологів в напрямку оволодіння доказовими медичними технологіями 3 надання дерматологічної, зокрема, косметологічної, допомоги;

- мотиваційна складова моделі, яка передбачає урахування інтересів усіх зацікавлених сторін: пацієнта (отримання комплексу ефективних послуг в одному місці їх надання, за лояльною ціною), лікаря (матеріальна мотивація до праці та до безперервного професійного розвитку) та закладу охорони здоров'я (отримання прибутку, конкурентноспроможність).

\section{Література}

1. Анатомія людини. Курс лекцій. Навч. пос. / Ю. Костиленко, І. Старченко, О. Прилуцький, В. Гринь. Полтава, 2015. - С. 42.

2. Білявська, М. В. Кореляція якості життя та психопатологічних порушень у пацієнтів, які страждають на псоріаз / М. В. Білявська, О. П. Романів // Економіка і право охорони здоров'я. - № 2 (8). - 2018. - С. 92 - 94.

3. Вороненко, Ю. В. Стоматологічна допомога в Україні: основні показники діяльності за 2008 - 2018 роки: довід. вид. / Ю. В. Вороненко, О. В. Павленко, І. В. Мазур. - Кропивницький, 2018. - 211 с.

4. Гірник, Г. Є. Вплив атопічного дерматиту на психологічний стан та соціальну адаптацію пацієнтів / Г. Є. Гірник // Галицький лікарський вісник. - 2015. - № 2. - С. 22 - 24.

5. Котуранова, Т. В. Проблеми та перспективи розвитку косметологічних послуг в Україні / Т. В. Котуранова, О. О. Семенова // Економічний простір. Зб. наук. пр. - № 119. - Дніпропетровськ: ПДАБА, 2017. - С. 77 - 85.

6. Кутасевич, Я. Ф. Стан ресурсів і діяльність дерматовенерологічної служби за 1998-2018 рр. в Україні. Нагальні задачі / Я. Ф. Кутасевич, В. М. Волкославська // Дерматологія та венерологія. - 2019. - № 2 (84). - С. 46-48.

7. Мурзіна, Е. О. Шкірні прояви ендокринних порушень / Е. О. Мурзіна // Клінічна імунологія. Алергологія. Інфектологія. - 2012, спец. вип. - № 1. - С. 79-84.

8. Ошивалова, О. О. Оцінка якості життя хворих з передонкологічною та онкологічною патологією шкіри / Ошивалова О. О., Зюков О. Л., Калюжна Л. Д. // Вісн. проблем біології і медицини. - 2017. - Вип. 2 (136). - С. $328-332$.

9. Хімейчук, Л. О. Сучасна косметологія як галузь медицини / Л. О. Хімейчук, Н. Ю. Сенишин, І. О. Буянова // Галицький лікарський вісник. - 2014. - № 1. - С. 73 - 75.

10. Черникова, Л. И. Дерматологические проявления патологии эндокринной системы / Л. И. Черникова, И. Н. Гончарова // Актуальні проблеми дерматології, венерології та ВІЛ/СНІД-інфекції : матеріали наук.-практ. конф. 3 міжнар. участю, присвяченої 155-річчю професору М. В. Тіпцева, Харків, 18 листопада 2015 р. / Харків : С.А.М., 2015. - C. 115-122.

11. Щорічна доповідь про стан здоров'я населення, санітарно-епідемічну ситуацію та результати діяльності системи охорони здоров’я України. 2017 рік. / МОЗ України. ДУ «УІСД МОЗ України». - Київ : МВС «Медінформ», 2018. - C. 107-119.

12. Strengthening people-centred health services delivery in the WHO European Region: concept note. - World Health Organization, 2014. $-19 \mathrm{p}$. 


\section{References}

1. Anatomiia liudyny [Human anatomy]. Kurs lektsii. Navch. pos. / Yu. Kostylenko, I. Starchenko, O. Prylutskyi, V. Hryn. - Poltava, 2015. - S. 42 [Ua].

2. Biliavska, M. V. Koreliatsiia yakosti zhyttia ta psykhopatolohichnykh porushen u patsiientiv, yaki strazhdaiut na psoriaz [Bilyavska, MV. Correlation of quality of life and psychopathological disorders in patients with psoriasis] / M. V. Biliavska, O. P. Romaniv // Ekonomika i pravo okhorony zdorovia. - № 2 (8). - 2018. - S. 92 - 94 [Ua].

3. Voronenko, Yu. V. Stomatolohichna dopomoha v Ukraini: osnovni pokaznyky diialnosti za 2008 - 2018 roky: dovid. vyd. [Voronenko, Yu. V. Dental care in Ukraine: main indicators of activity for 2008 - 2018] / Yu. V. Voronenko, O. V. Pavlenko, I. V. Mazur. - Kropyvnytskyi, 2018. - 211 s [Ua].

4. Hirnyk, H. Ye. Vplyv atopichnoho dermatytu na psykholohichnyi stan ta sotsialnu adaptatsiiu patsiientiv [Girnyk, GE. Effect of atopic dermatitis on the psychological state and social adaptation of patients] / H. Ye. Hirnyk // Halytskyi likarskyi visnyk. - 2015. - № 2. - S. 22 - 24 [Ua].

5. Koturanova, T. V. Problemy ta perspektyvy rozvytku kosmetolohichnykh posluh v Ukraini [Koturanova, TV. Problems and prospects of development of cosmetology services in Ukraine] / T. V. Koturanova, O. O. Semenova // Ekonomichnyi prostir. Zb. nauk. pr. - № 119. - Dnipropetrovsk: PDABA, 2017. - S. 77 - 85 [Ua].

6. Kutasevych, Ya. F. Stan resursiv i diialnist dermatovenerolohichnoi sluzhby za 1998-2018 rr. v Ukraini. Nahalni zadachi [Kutasevich, YF. The state of resources and activity of the dermatovenerological service for 1998-2018 in Ukraine. Urgent tasks] / Ya. F. Kutasevych, V. M. Volkoslavska // Dermatolohiia ta venerolohiia. - 2019. - № 2 (84). - S. 46-48 [Ua].

7. Murzina, E. O. Shkirni proiavy endokrynnykh porushen [Murzina, EO. Skin manifestations of endocrine disorders] / E. O. Murzina // Klinichna imunolohiia. Alerholohiia. Infektolohiia. - 2012, spets. vyp. - № 1. - S. 79-84 [Ua].

8. Oshyvalova, O. O. Otsinka yakosti zhyttia khvorykh z peredonkolohichnoiu ta onkolohichnoiu patolohiieiu shkiry [Oshivalova, OO. Assessment of quality of patients life with precancerous and oncological skin pathology] / Oshyvalova O. O., Ziukov O. L., Kaliuzhna L. D. // Visnyk problem biolohii i medytsyny. - 2017. - Vyp. 2 (136). - S. 328-332 [Ua].

9. Khimeichuk, L. O. Suchasna kosmetolohiia yak haluz medytsyny [Khimeychuk, LO. Modern cosmetology as a branch of medicine] / L. O. Khimeichuk, N. Yu. Senyshyn, I. O. Buianova // Halytskyi likarskyi visnyk. - 2014. - № 1. - S. 73-75 [Ua].

10. Chernikova, L. I. Dermatologicheskie proyavleniya patologii endokrinnoy sistemy [Chernikova, LI. Dermatological manifestations of the endocrine system pathology] / L. I. Chernikova, I. N. Goncharova // Aktualni problemy dermatolohii, venerolohii ta VIL/SNID-infektsii : materialy nauk.-prakt. konf. z mizhnar. uchastiu, prysviachenoi 155-richchiu profesoru M. V. Tiptseva, Kharkiv, 18 lystopada 2015 r. / Kharkiv : S.A.M., 2015. - S. 115-122 [Ru].

11. Shchorichna dopovid pro stan zdorovia naselennia, sanitarno-epidemichnu sytuatsiiu ta rezultaty diialnosti systemy okhorony zdorovia Ukrainy. 2017 rik [Annual report on the state of population health, the sanitary-epidemic situation and the results of health care system activity of Ukraine. 2017] / MOZ Ukrainy. DU «UISD MOZ Ukrainy». - Kyiv : MVS «Medinform», 2018. - S. 107-119 [Ua].

12. Strengthening people-centred health services delivery in the WHO European Region: concept note. - World Health Organization, 2014. - 19 p. [En].

Дата надходження рукопису до редакції: 05.02.2020 p.

Мета: обгрунтувати та розробити удосконалену модель організації медичної допомоги пацієнтам 3 патологічними та віковими змінами шкіри.

Матеріали та методи: дані результатів власного дослідження автора як фрагменту науково-дослідної роботи кафедри управління охороною здоров’я НМАПО імені П.Л. Шупика. Методи системного підходу і аналізу, синтезу, моделювання.

Результати: доцільність розробки удосконаленої моделі обумовлена: недосконалістю нормативно-правового регулювання організації дерматовенерологічної допомоги; вузькоспеціалізованим підходом до лікування хвороб шкіри та коригування вікових змін, відсутністю обгрунтованих механізмів взаємодії надавачів медичних послуг; низьким освітнім рівнем пацієнтів 3 питань збереження здоров'я шкіри; обмеженим використанням в косметологічній практиці доказових технологій. Ключовими елементами удосконаленої моделі запропоновані: типова програма комплексної медичної допомоги пацієнту 3 патологічними та віковими змінами шкіри; удосконалені технології освітньопрофілактичної роботи з населенням; міждисциплінарні команди фахівців; доказові технології косметологічної допомоги; мотиваційні ресурси.

Висновки: запропонована удосконалена модель може бути впроваджена в діяльність багатопрофільних закладів охорони здоров'я будь-якої форми власності.

Ключові слова: модель, комплексна медична допомога, патологічні та вікові зміни шкіри.

Цель исследования: обосновать и разработать усовершенствованную модель организации медицинской помощи пациентам с патологическими и возрастными изменениями кожи. 
Материалы и методы: данные результатов собственного исследования автора как фрагмента научноисследовательской работы кафедры управления здравоохранением НМАПО имени П.Л. Шупика. Использованы методы системного подхода и системного анализа, синтеза, моделирования.

Результаты: целесообразность разработки усовершенствованной модели обусловлена: несовершенством нормативно-правового регулирования организации дерматовенерологической помощи; узкоспециализированным подходом к лечению болезней кожи и коррекции возрастных изменений, отсутствием обоснованных механизмов взаимодействия поставщиков медицинских услуг; низким образовательным уровнем пациентов по вопросам сохранения здоровья кожи; ограничением использования в косметологической практике доказательных технологий. Ключевыми элементами усовершенствованной модели предложены: типовая программа комплексной медицинской помощи пациенту с патологическими и возрастными изменениями кожи; усовершенствованные технологии образовательно-профилактической работы с населением; междисциплинарные команды специалистов; доказательные технологии косметологической помощи; мотивационные ресурсы.

Выводы: усовершенствованная модель может быть внедрена в деятельность многопрофильных учреждений здравоохранения любой формы собственности.

Ключевые слова: модель, комплексная медицинская помощь, патологические и возрастные изменения кожи.

The aim of the study was to justify and develop an improved model for organizing medical care for patients with pathological and age-related skin changes.

Materials and methods: the results of the author's research as a fragment of the scientific research work of Health Management Department. The methods of a systematic approach, analysis, synthesis, modeling were used.

Results: the imperfection of the legal regulation of dermatovenereological care, a narrow specialized approach to the treatment of skin diseases and correction of aging, the lack of mechanisms for interaction between healthcare providers, the low patients educational level on skin health, the lack of evidence-based technologies were the reason for the development of the model. The key elements of the improved model are: a typical program of integrated medical care; advanced preventive technologies for the population; multidisciplinary teams of specialists; evidence-based technologies for cosmetology care; motivational resources.

Conclusions: an improved model can be implemented in the activities of multidisciplinary healthcare institutions.

Key words: model, integrated medical care, pathological and age-related skin changes.

\section{Відомості про автора}

Глєбова Свгенія Свгеніївна - аспірант кафедри управління охороною здоров'я Національної медичної академії післядипломної освіти імені П. Л. Шупика; м. Київ, вул. Дорогожицька, 9, офіс 46. +380 (44) 205-49-90, doc.e.glebova@gmail.com.

\section{Контактна особа для листування (науковий керівник)}

Горачук Вікторія Валентинівна - доктор медичних наук, професор, професор кафедри управління охороною здоров'я Національної медичної академії післядипломної освіти імені П. Л. Шупика; м. Київ, вул. Дорогожицька, 9, офіс 55-а. +380 (44) 205-49-93, +380 (73) 504-04-50, gorachuk@ukr.net. 